\title{
Hubungan Perbedaan Gender Terhadap Keputusan Dalam Membeli Produk Pakaian Jadi
}

\author{
RONI ANDESPA \\ Sekolah Tinggi Ilmu Ekonomi Riau (STIER) \\ Jln. HR. Subrantas 57 Panam Pekanbaru 28293 Telp. (0761) 63237 \\ E-mail : akbar_stier@yahoo.com
}

\begin{abstract}
Interest in consumer purchasing in buying apparel products, is the data that is needed by every company engaged in the garment industry. Moreover purchase interest between men and women, as consideration for a company in producing clothes based on sex. Where the consumer or customer purchase interest is seen by sex or gender can be utilized as a marketing strategy for companies involved in the garment or apparel industry which will serve as a decision-making materials in the production, so that the products according to market needs and wants. Well adapted to the development of rapid business world, and evolving market conditions are more and more product choices for consumers has had impact on marketing strategies to be adopted by companies in offering and marketing their products, so the company claimed to have advantages in the competition. The study aimed to determine whether there is a relationship between gender consumers with the type of clothes you buy, and to know the real influence of gender on the type of consumers who purchased apparel. Where the samples used in the study were 300 respondents in the Batusangkar City, Tanah Datar, West Sumatra. From the research we can conclude that there was a significant relationship between gender differences with the intention to purchase apparel, and there was indeed a fairly strong influence of gender differences on consumer purchase interest.
\end{abstract}

Keywords: Gender, Purchase Decision, Consumer Behavior, Garments

Minat beli konsumen dalam membeli produk pakaian jadi, merupakan data yang sangat dibutuhkan oleh setiap perusahaan yang bergerak dibidang industri garmen, terutama sekali untuk data pemasaran perusahaan.

Terlebih lagi minat beli antara pria dan wanita, sebagai bahan pertimbangan bagi perusahan didalam memproduksi pakaian berdasarkan jenis kelamin.

sehingga mengetahui kebutuhan pasar atau jenis dan bentuk pakaian yang memang dibutuhkan oleh konsumen di sesuaikan dengan perkembangan zaman.

Dimana minat beli konsumen atau pelanggan dipandang berdasarkan jenis kelamin atau gender bisa dimanfaatkan menjadi sebuah strategi pemasaran bagi perusahaan yang bergerak di industri garmen atau pakaian jadi yang nantinya dijadikan sebagai bahan pengambilan keputusan dalam produksi pakaian jadi. Sehingga produk sesuai dengan kebutuhan dan keinginan pasar. Serta produk yang dihasilkan disesuaikan dengan perkembangan dunia bisnis yang semakin pesat dan tingkat persaingan yang semaki tinggi, serta perkembangan kondisi pasar dimana konsumen yang memiliki semakin banyak pilihan produk.

Dimana seorang konsumen dengan mudah untuk mendapatkan produk yang sesuai dengan keinginan dan kebutuhannya, hal ini telah membawa pengaruh terhadap strategi pemasaran yang harus diterapkan oleh perusahaan dalam menawarkan dan memasarkan produk mereka, sehingga perusahaan dituntut untuk memiliki keunggulan didalam persaingan bisnis.

$$
\text { Perilaku pembelian seseorang }
$$

konsumen dapat dikatakan sesuatu yang sangat unik dan spesifik, masing-masing konsumen memiliki sudut padang yang berbeda terhadap suatu produk ataupun merek.

Karena preferensi dan sikap terhadap objek setiap orang berbeda. Selain itu konsumen berasal dari beberapa segmen, 
sehingga apa yang diinginkan dan dibutuhkan juga berbeda berdasarkan karakteristik dan latar belakang yang mereka miliki.

Masih terdapat banyak faktor yang berpengaruh terhadap minat beli konsumen. Produsen perlu memahami perilaku konsumen terhadap produk atau merek yang dilemparkan ke pasar, selanjutnya perlu dilakukan berbagai strategi dan cara untuk membuat konsumen tertarik terhadap produk yang dihasilkan dan dilemparkan ke pasar.

Karena bagi perusahaan yang berorientasi pada kebutuhan konsumen (pasar), maka kegiatan pemasaran akan bermula dari konsumen dan berakhir pada konsumen. Artinya dimulai dari menetukan apa yang diinginkan konsumen dan diakhiri dengan kepuasan konsumen, yang nantinya memiliki efek terhadap loyalitas konsumen tentunya.

Konsmen yang puas akan loyal kepada perusahaan, konsumen yang loyal akan merekomendasikan kepada orang yang dikenalnya untuk mengkonsumsi produk, dan muaranya kepada peningkatan profit perusahaan dan perkembangan perusahaan.

Dari konsep pemasaran jelaslah bahwa perusahaan harus mampu memberikan pelayanan kepada konsumennya dengan mengetahui apa yang menjadi kebutuhannya agar perusahaan dapat bertahan dan berkembang.

Perumusan masalah yang ada dalam penelitian adalah bagaimana hubungan antara perbedaan gender konsumen dengan jenis pakaian yang dibeli, dan bagaimana pengaruh yang nyata dari perbedaan gender konsumen terhadap jenis pakaian jadi yang dibeli atau dipilihnya.

Tujuan penelitian adalah untuk mengetahui apakah ada hubungan antara perbedaan gender konsumen dengan jenis pakaian yang dibeli, serta untuk mengetahui pengaruh yang nyata dari perbedaan gender konsumen terhadap jenis pakaian jadi yang dibeli atau dipilihnya.

Defenisi Pemasaran menurut Philip Kotler (2002:9) adalah: "Pemasaran merupakan suatu proses sosial yang di dalamnya individu dan kelompok mendapatkan apa yang mereka butuhkan dan inginkan dengan menciptakan, menawarkan dan secara bebas mempertukarkan produk yang bernilai dengan pihak lain".

Pemasaran sering di gambarkan sebagai seni menjual produk akan tetapi orang heran ketika mendengar bahwa bagian yang paling penting dalam pemasaran bukan penjualan. Penjualan hanya merupakan puncak kecil gunung Es pemasaran.

Menurut Philip Kotler (2002:9) bahwa, salah satu tujuan pemasaran adalah untuk mengetahui dan memahami pelanggan sedemikian rupa sehingga produk atau jasa cocok dengan pelanggan dan selanjutnya menjual dirinya sendiri. Pemasaran hendaknya menghasilkan seorang pelanggan yang siap untuk membeli.

Menurut American Marketing Association yang di kutip dari buku Pemasaran oleh Lamb, Hair dan McDaniel (2001:6) "Marketing is the process of planning and executing the conception, pricing, promotion, and distribution of ideas, goods, and service to create exchanges that satisfy individual and organization goals".

Menurut Asosiasi Pemasaran Amerika, yang dikutip dari buku Philip Kotler (2002:9), Pemasaran adalah: "Proses perencanaan dan pelaksanaan pemikiran, penetapan harga, promosi serta penyaluran gagasan, barang dan jasa untuk menciptakan pertukaran yang memenuhi sasaran-sasaran individu dan organisasi.

Manajemen pemasaran terjadi bila sekurang-kurangnya satu pihak pelaku pertukaran potensial berpikir tentang saranasarana untuk melaksanakan tanggapan yang diinginkan oleh pihak pertama itu dari pihak lain.

Henry Simamora

(2000:4)

menyatakan bahwa Pemasaran Internasional (International Marketing) paling baik di jelaskan terlebih dahulu meninjau secara ringkas pemasaran dalam konteks Domestik.

Dalam konteks Domestik, menurut Henry Simamora (2000:4), Pemasaran merupakan: "Proses manajerial dan sosial dimana individu-individu dan kelompok- 
kelompok memperoleh apa yang mereka butuhkan dan inginkan melalui penciptaan, penawaran dan pertukaran produk-produk yang bernilai dengan orang dan atau kelompok lain.

Suatu perusahaan mesti memantau aktivitas-aktivitas pamasaran pesaing domestik dan internasionalnya dan menyusun berbagai strategi pemasaran jangka panjang dan respon-respon kompetitif yang tepat.

Dengan demikian manajemen pemasaran merupakan perencanaan dan pengkoordinasian semua aktivitas tersebut untuk mencapai sebuah program pemasaran yang berintegrasi secara berhasil.

Konsep Pemasaran

Saat ini pandangan terhadap pemasaran telah mengalami perubahan dari sebelumnya. Pada mulanya pemasaran di pandang tidak jauh dari penjualan. Dengan timbulnya kesadaran untuk meningkatkan efisiensi.

Maka berangsur-angsur orang menyadari memuaskan kebutuhan pelanggan sangat penting untuk meraih kesuksesan.

Dalam pandangan Stanton (1995) dalam buku "Riset pemasaran dan perilaku konsumen”, Husein Umar (2003:31), Stanton menyatakan bahwa "Pemasaran meliputi keseluruhan sistem yang berhubungan dengan kegiatan-kegiatan usaha, yang bertujuan merencanakan, menentukan harga hingga mempromosikan dan mendistribusikan barang dan jasa yang akan memuaskan kebutuhan pembeli, baik yang aktual maupun yang potensial.

Jangkauan pemasaran sangat luas, berbagai tahap kegiatan harus dilalui oleh barang dan jasa sebelum sampai ke tangan konsumen, sehingga ruang lingkup kegiatan yang luas itu di sederhanakan menjadi 4 (empat) kebijakan pemasaran yang lazim di sebut dengan bauran pemasaran (Marketing Mix) atau 4P dalam pemasaran yang terdiri dari :

\section{Produk (Product)}

Pengertian produk bagi konsumen selain merupakan benda yang mempunyai manfaat dan kegunaan juga merupakan suatu yang dapat ditawarkan kepasar untuk mendapatkan perhatian untuk di beli, digunakan atau di konsumsi yang dapat memenuhi suatu kegiatan atau kebutuhan.

Pengembangan sebuah produk menghasilkan perusahaan menetapkan manfaat-manfaat apa yang akan di berikan produk itu.. Manfaat ini dikomunikasikan dan hendaknya di penuhi oleh atribut produk. 2. Harga (Price)

Harga adalah faktor utama yang harus di tentukan sebelum suatu produk di luncurkan ke pasar sasaran. Harga produk juga salah satu faktor penentu bagi permintaan pasar yang secara otomatis akan mempengaruhi volume penjualan.

Jika harga produk tidak dapat di jangkau konsumen, maka target penjualan yang telah di tetapkan tidak tercapai.

"Harga menurut Husein Umar (2003:71) adalah sejumlah nilai yang di tukarkan konsumen dengan manfaat dari memiliki atau menggunakan produk atau jasa yang nilainya ditetapkan oleh pembeli dan penjual melalui tawar menawar atau di tetapkan oleh penjual untuk satu harga yang sama terhadap semua pembeli."

3. Distribusi (Place)

Sebagian besar produsen menggunakan perantara pemasaran untuk memasarkan produk khususnya barang dengan cara membangun suatu saluran distribusi yang meliputi sekelompok organisasi yang saling tergantung dalam keterlibatan mereka pada proses yang memungkinkan suatu produk atau jasa tersedia bagi penggunaan atau konsumsi oleh konsumen atau pengguna industrial.

4. Promosi (Promotion)

Konsep pemasaran tidak hanya membicarakan mengenai produk, harga produk dan mendistribusikan produk, tetapi juga mengkomunikasikan produk ini kepada masyarakat agar produk itu di kenal dan ujung-ujungnya di beli.

Menurut Boyd, Wolker, dan Larreche (2000:65) menyatakan strategi promosi merupakan "Sebuah program terkendali dan terpadu dari metode komunikasi dan material yang di rancang untuk menghadirkan perusahaan dan produk-produknya kepada 
calon konsumen, menyampaikan ciri-ciri produk yang memuaskan kebutuhan untuk mendorong penjualan yang pada akhirnya memberikan kontribusi pada kinerja laba jangka panjang.

Perilaku konsumen yang tidak dapat di kendalikan secara langsung oleh perusahaan perlu di cari informasinya semaksimal mungkin. Perilaku konsumen memiliki kepentingan khusus bagi orang karena berbagai alasan, berhasrat mempengaruhi atau merubah perilaku itu, termasuk mereka yang berkepentingan utamanya adalah pemasaran, pendidikan dan perlindungan serta kebijakan umum.

$$
\text { Perilaku konsumen sangat }
$$

menentukan dalam proses pengambilan keputusan membeli yang tahapnya di mulai dari pengenalan masalah oleh manusia, berupa desakan yang membangkitkan tindakan untuk memenuhi dan memuaskan terhadap kebutuhannya.

Semakin majunya perekonomian dan perkembangan zaman yang semakin pesat, harus beriringan dengan perkembangan strategi pemasaran yang harus dijalankan dan diterapkan oleh perusahaan.

Untuk itu perusahaan perlu memahami atau mempelajari perilaku konsumen dalam hubungannya dengan pembelian yang dilakukan oleh konsumen tersebut.

Dalam menentukan jenis produk atau jasa, konsumen selalu mempertimbangkan tentang produk atau jasa apa yang dibutuhkan, hal ini dikenal dengan perilaku konsumen.

Menurut Lamb, Hair, dan McDaniel (2001:188) Perilaku konsumen merupakan "Proses seorang pelanggan dalam membuat keputusan membeli, juga untuk menggunakan dan membuang barang-barang dan jasa-jasa yang di beli, juga termasuk faktor yang mempengaruhi keputusan pembelian dan penggunaan produk".

Menurut Husein Umar (2003:64) perilaku konsumen adalah :"Suatu tindakan yang langsung dalam mendapatkan, mengkonsumsi serta menghabiskan produk dan jasa, termasuk proses keputusan yang mendahului dan penyusuli tindakan tersebut".

Memahami bagaimana seorang konsumen dalam membuat keputusan pembelian, akan membantu seorang manajer pemasaran dalam banyak hal, terutama sekali mengestimasi jenis, bentuk dan merek dari sebuah produk yang akan dilemparkan kepasar, sehingga produk yang dibuat dapat disesuaikan dengan kebutuhan dan keinginan dari konsumen

Titik tolak untuk memahami perilaku pembeli adalah model rangsangan-tanggapan pemasaran dengan pembeli.

Model Prilaku Konsumen Menurut Khotler

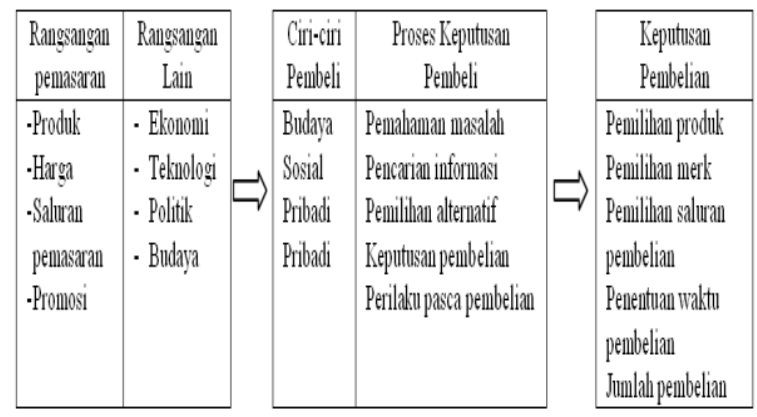

Gambar 1. Model Prilaku Konsumen, Khotler (2002)

Model Prilaku Konsumen Menurut Assael

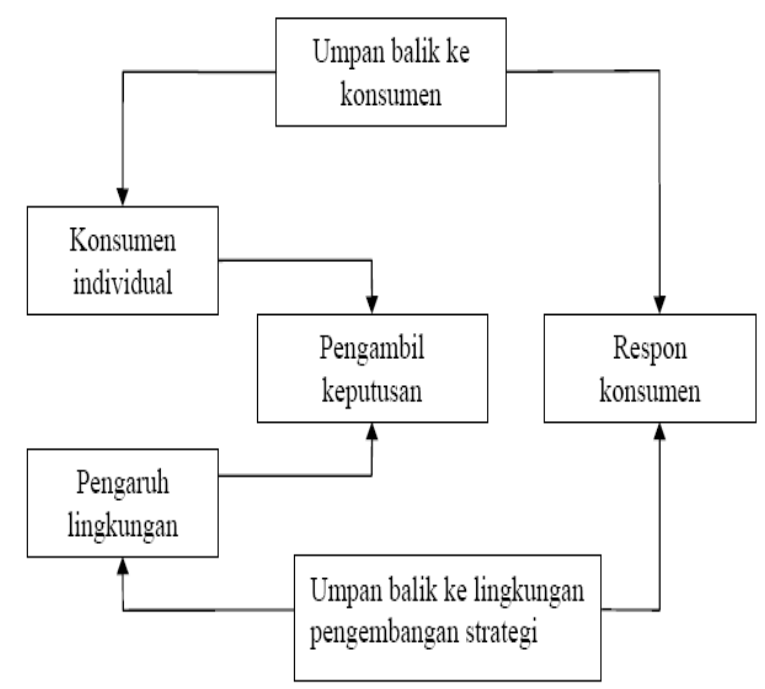

Gambar 2. Model Prilaku Konsumen, Assael (2002)

Model perilaku konsumen yang dikembangkan Assael bahwa proses keputusan konsumen dalam pembelian ditekankan pada tiga faktor yaitu : 
a. Stimuli

Stimuli menunjukkan penerimaan informasi oleh konsumen dan pemprosesan informasi terjadi saat konsumen mengevaluasi informasi dari periklanan, teman atau pengalaman sendiri.

b. Karakteristik Pribadi Konsumen

Karakteristik pribadi konsumen meliputi persepsi, sikap, manfaat serta karakteristik konsumen (demografi, kepribadian, gaya hidup).

c. Respon Konsumen

Respon konsumen adalah hasil akhir dari proses keputusan konsumen dan suatu pertimbangan yang menyeluruh sehingga melakukan pembelian terhadap produk.

Sikap dan perilaku konsumen juga merupakan bagian dari konsep perilaku konsumen yang lain. Untuk mengukur sikap dan perilaku konsumen dapat dengan Model Multi atribut.

Salah satu model sikap yang terkenal adalah model sikap multiatribut dari Fishbein. Model sikap Fishbein ini berfokus pada prediksi sikap yang di bentuk seseorang terhadap objek tertentu. Model ini mengidentifikasi tiga faktor utama untuk memprediksi sikap, meliputi:

Pertama : Keyakinan seseorang terhadap atribut yang menonjol dari objek.

Kedua : Kekuatan keyakinan seseorang bahwa atribut memiliki atribut khas, biasanya di ketahui dalam bentuk pertanyaan.

Ketiga : Evaluasi dari masing-masing keyakinan akan atribut yang menonjol, dimana di ukur seberapa baik atau tidak baik keyakinan mereka terhadap atribut-atribut tersebut.

Minat beli konsumen merupakan kecenderungan konsumen untuk membeli suatu merek atau mengambil tindakan yang berhubungan dengan pembelian yang diukur dengan tingkat kemungkinan konsumen melakukan pembelian (Assael, 2001).

Faktor-faktor yang mempengaruhi Prilaku Konsumen didalam memutuskan untuk membeli adalah :

\section{Faktor Marketing Mix}

Para pemasar menggunakan sejumlah alat untuk mendapatkan tanggapan yang diinginkan dari pasar sasaran mereka, alatalat itu membentuk suatu bauran pemasaran.

Dalam pandangan Lamb, Hair, McDaniel (2001:55) bauran pemasaran mengacu pada paduan strategi produk, distribusi, promosi, dan penentuan harga yang bersifat unik yang dirancang untuk menghasilkan pertukaran yang saling memuaskan dengan pasar yang dituju.

\section{Menurut Philip Kotler (2002:18),} pengertian Marketing Mix adalah “ Seperangkat alat pemasaran yang digunakan perusahaan untuk terus-menerus mencapai tujuan pemasarannya di pasar sasaran ".

Jika sasaran pasarnya sudah ditentukan melalui riset pemasaran, maka perusahaan harus membuat suatu rencana yang baik untuk memasuki segmen pasar yang dipilih. Keputusan-keputusan dalam pemasaran dapat dikelompokkan dalam beberapa bauran :

a. Produk

Pengertian produk bagi konsumen selain merupakan benda yang mempunyai manfaat dan kegunaan juga merupakan suatu yang dapat ditawarkan kepasar untuk mendapatkan perhatian untuk di beli, digunakan atau di konsumsi yang dapat memenuhi suatu kegiatan atau kebutuhan.

Pengembangan sebuah produk menghasilkan perusahaan menetapkan manfaat-manfaat apa yang akan di berikan produk itu.. Manfaat ini dikomunikasikan dan hendaknya di penuhi oleh atribut produk. b. Harga

Harga adalah faktor utama yang harus di tentukan sebelum suatu produk di luncurkan ke pasar sasaran. Harga produk juga salah satu faktor penentu bagi permintaan pasar yang secara otomatis akan mempengaruhi volume penjualan. Jika harga produk tidak dapat di jangkau konsumen, maka target penjualan yang telah di tetapkan tidak tercapai, sedikit saja selisih harga dengan harga yang ditawarkan pesaing untuk pindah ke pesaing, karena harga merupakan 
faktor yang sangat sensitif bagi seorang konsumen dalam membeli.

"Harga menurut Husein Umar (2003:32) adalah sejumlah nilai yang di tukarkan konsumen dengan manfaat dari memiliki atau menggunakan produk atau jasa yang nilainya ditetapkan oleh pembeli dan penjual melalui tawar menawar atau di tetapkan oleh penjual untuk satu harga yang sama terhadap semua pembeli.

c. Promosi

Pembahasan pemasaran tidak hanya membicarakan mengenai produk, harga produk dan mendistribusikan produk, tetapi juga mengkomunikasikan produk ini kepada masyarakat agar produk itu di kenal dan ujung-ujungnya di beli oleh konsumen.

Menurut Boyd, Walker, dan Larreche (2000:65) menyatakan strategi promosi merupakan "Sebuah program terkendali dan terpadu dari metode komunikasi dan material yang di rancang untuk menghadirkan perusahaan dan produkproduknya kepada calon konsumen, menyampaikan ciri-ciri produk yang memuaskan kebutuhan untuk mendorong penjualan yang pada akhirnya memberikan kontribusi pada kinerja laba jangka panjang.

Menurut Basu Swasta (2000) promosi adalah :"Arus informasi atau persuasi satu arah yang dibuat untuk menciptakan pertukaran dalam pemasaran". Selain juga harus memperkerjakan, melatih dan memotivasi wiraniaganya.

2. Faktor Budaya

a. Budaya

Budaya menurut Philip Kotler (2002:183) adalah "merupakan penentu keinginan dan perilaku yang paling mendasar"

Menurut Lamb, Hair, McDaniel (2001:202) :"Faktor budaya adalah karakter yang penting dari suatu sosial yang membedakannya dari kelompok kultur yang lainnya".

b. Kelas sosial

Kelas Sosial menurut Lamb, Hair, McDaniel (2001:210) adalah menyebut kelas sosial dengan defenisi sebagai berikut "Merupakan sekelompok orang yang sama- sama mempertimbangkan secara dekat persamaan di dalam status atau penghargaan komunitas yang secara terus-menerus bersosialisasi di antara mereka sendiri baik secara formal dan informal, dan yang membagikan norma-norma perilakunya".

Defenisi dari kelas sosial adalah "Pembagian masyarakat yang relatif homogen dan permanen yang tersusun secara hierarkis dan yang anggotanya menganut nilai-nilai, minat dan perilaku yang serupa".

Kelas sosial menunjukan preferensi produk dan merek yang berbeda dalam banyak hal.

3. Faktor Sosial

a. Kelompok Acuan

Kelompok acuan menurut Philip Kotler (2000:187) merupakan "Semua kelompok yang memiliki pengaruh langsung (tatap muka) atau tidak langsung terhadap sikap atau perilaku seseorang"

Orang sangat di pengaruhi oleh kelompok acuan, mereka sekurangkurangnya melalui tiga jalur : Kelompok acuan menghadapkan seseorang pada perilaku dan gaya hidup baru. Kelompok acuan juga mempengaruhi perilaku dan konsep pribadi seseorang. Dan kelompok menciptakan tekanan untuk mengikuti kebiasaan kelompok yang mungkin mempengaruhi pilihan produk dan merek aktual dari seseorang konsumen.

b. Keluarga

Keluarga menurut Philip Kotler (2000:188) merupakan organisasi pembelian konsumen yang paling penting dalam masyarakat dan ia telah menjadi objek penelitian yang luas. Anggota keluarga merupakan kelompok acuan primer yang paling berpengaruh.

Menurut Lamb, Hair, McDaniel (2001:217) keluarga merupakan :'Institusi sosial yang paling penting bagi beberapa konsumen, karena secara kuat mempengaruhi nilai, sikap, konsep pribadi, dan perilaku pembelian.

c. Peran dan Status

Seseorang berpartisipasi kedalam banyak kelompok sepanjang hidupnya, 
keluarga, klub, ataupun organisasi. Kedudukan orang itu di masing-masing kelompok dapat di tentukan berdasarkan peran dan status.

Peran merupakan kegiatan yang di harapkan dilakukan oleh seseorang. Status merupakan masing-masing, dari peran tersebutlah yang natinya akan menghasilkan status.

\section{Faktor Pribadi}

Keputusan di dalam pembelian juga di pengaruhi karakteristik pribadi sesorang yang terdiri dari:

a. Usia dan tahap siklus hidup

Beberapa karya terbaru telah mengidentifikasi tahap siklus hidup psikologis orang dewasa mengalami "perjalanan" dan "perubahan" sepanjang hidupnya. Seorang pemasar yang baik akan memberikan perhatian yang besar dan khusus pada perubahan situasi hidup-bercerai dan dampak situasi itu terhadap perilaku konsumsi sesorang konsumen.

b. Gaya hidup

Merupakan pola hidup seseorang didunia yang diekspresikan dalam aktivitas, minat dan opininya. Gaya hidup menggambarkan keseluruhan diri seseorang yang berinteraksi dengan lingkungannya.

c. Kepribadian dan konsep diri

Maksud dari kepribadian yaitu merupakan karakteristik psikologis seseorang yang berbeda dengan orang lain yang menyebabkan tanggapan yang relatif konsisten dan bertahan lama terhadap lingkungannya.

Kepribadian biasanya dijelaskan dengan menggunakan ciri-ciri seperti kepercayaan diri, dominasi, otonomi, kehormatan, kemampuan berorientasi, pertahanan diri, dan kemampuan beradaptasi.

Kepribadian dapat menjadi variabel yang sangat berguna dalam menganalisis prilaku konsumen, asalkan jenis kepribadian tersebut dapat diklasifikasikan dengan akurat dan asalkan terdapat korelasi yang kuat antara jenis kepribadian tertentu dengan pilihan produk atau merek.
Yang juga berkaitan dengan kepribadian adalah konsep diri seseorang. Pemasar yang jeli akan berusaha mengembangkan citra merek yang sesuai dengan citra pribadi pasar sasaran dari perusahaan, dan dengan kepribadian serta karakteristik khusus yang dimiliki konsumen.

\section{Faktor Psikologis}

Pilihan pembelian seseorang konsumen dapat di pengaruhi oleh empat faktor psikologis yaitu:

a. Motivasi

Motivasi merupakan kebutuhan yang cukup mendorong seseorang untuk bertindak melakukan sesuatu.

Tiga teori tentang motivasi :

Teori Freud

Dimana Sigmonund Freud mengasumsikan bahwa kekuatan psikologis yang membentuk perilaku manusia sebagian besar tidak disadari dan bahwa seseorang tidak memahami motivasi dirinya secara menyeluruh.

Teori Maslow

Disini Abraham Maslow berusaha menjelaskan mengapa orang didorong oleh kebutuhan-kebutuhan tertentu pada waktuwaktu tertentu.

\section{Teori Herzberg}

Dimana Federick Herzberg mengembangkan teori motivasi dua faktor yang membedakan Dissatisfier (faktor yang menyebabkan ketidakpuasan) dan Satisfier (faktor yeng menyebabkan kepuasan).

b. Persepsi

Bagaimana seseorang yang termotivasi bertindak akan dipengaruhi oleh persepsinya terhadap situasi tertentu.

Persepsi menurut Lamb, Hair, McDaniel (2001:224) :’Proses dimana kita memilih, mengatur dan menginterpretasikan ransangan tersebut ke dalam gambaran yang memberi makna dan melekat.

Menurut Philip Kotler (2002:198), persepsi merupakan proses yang digunakan seorang individu untuk memilih mengorganisasi dan menginterpretasi 
masukan-masukan informasi guna menciptakan gambaran dunia yang memiliki arti.

\section{c. Pembelajaran}

Pembelajaran menurut Philip Kotler (2002:198) merupakan perubahan perilaku seseorang yang timbul dari pengalaman.

Sebagian besar perilaku manusia adalah hasil dari belajar. Teori pembelajaran mengajarkan ke para pemasar bahwa mereka dapat membangun permintaan atas sebuah produk yang mengaitkannya pada dorongan yang kuat menggunakan petunjuk yang memberikan dorongan atau motivasi dan memberikan penguatan yang positif.

\section{d. Keyakinan dan sikap}

Keyakinan mungkin berdasarkan pengetahuan pendapat atau kepercayaan kesemuanya itu mungkin atau tidak mungkin mengandung faktor emosional.

Keyakinan itu membentuk citra produk dan merk dan orang akan bertindak berdasarkan citra tersebut.

Jika beberapa keyakinan mengenai tempat salah dan menghambat pembelian, perusahaan manufaktur akan berusaha meluncurkan kampanye untuk mengoreksi dan memperbaiki keyakinan-keyakinan tersebut.

Adapun keyakinan menurut Philip Kotler (2002:199) yaitu merupakan " suatu gambaran pikiran yang dianut seseorang tentang sesuatu hal ".

Defenisi sikap menurut Philip Kotler (2002:200), sikap merupakan "Evaluasi, perasaan, emosional dan kecenderungan tindakan yang menguntungkan atau tidak menguntungkan dan bertahan lama dari seseorang terhadap suatu objek.

Kotler (2002) mengungkapkan bahwa berbagai teori tentang proses manajemen pemasaran, perilaku pengambilan keputusan dan organisasi perilaku konsumen dapat dibuat model strategi pemasaran. Sebagai inti dari model ini adalah perilaku pembelian. Perilaku pembelian dipengaruhi oleh tiga hal yaitu perbedaan individu, kondisi lingkungan dan usaha pemasaran (marketing mix).

Untuk mencapai keberhasilan pemasaran perusahaan perlu menyusun kebijakan pemasaran yang tepat sesuai dengan sasaran yang akan dituju. Marketing mix (bauran pemasaran) merupakan strategi pemasaran yang terdiri dari empat variabel (4P) yakni : produk, harga, promosi dan distribusi. Mengingat keinginan konsumen yang selalu berubah, perusahaan dapat mengembangkan variabel-variabel bauran pemasaran sesuai dengan keinginan konsumen potensial. Sehingga dengan demikian usaha pemasaran tidak hanya bertumpu pada 4P saja tetapi dapat dikembangkan menjadi 7P.

Dapat dibuat hipotesis untuk penelitan ini, yaitu:

1. $\mathrm{H} 1$ = Diduga terdapat hubungan antara perbedaan gender konsumen dengan jenis pakaian jadi yang dibeli atau dipilihnya.

2. $\mathrm{H} 2$ = Diduga terdapat pengaruh yang nyata dari perbedaan gender konsumen terhadap jenis pakaian jadi yang dibeli atau dipilihnya.

\section{METODE}

Populasi yang digunakan adalah seluruh konsumen pakaian jadi yang ada di kota Batusangkar, Kabupaten Tanah Datar, Sumatera Barat.

Sampel yang digunakan adalah sebanyak 300 konsumen dari populasi konsumen yang ada, teknik pengambilan sampel yang digunakan adalah metode non probability sampling dengan Convenience sampling, mengingat dimana jumlah populasi yang cukup besar.

Maka setiap konsumen pakaian jadi yang mudah untuk ditemui, dan rasanya bisa untuk menjadi sampel, maka berhak untuk menjadi responden di dalam penelitan, hal ini dilakukan untuk diagnosis situasi secara cepat dan bersifat sederhana dan mudah karena keterbatasan waktu penelitian.

Data yang digunakan adalah data primer yang diperoleh melalui penyebaran kuesioner kepada responden yang dijadikan 
sampel dengan pertanyaan tertutup dimana skala pengukurannya menggunakan skala.

Dimana angka 1 mewakili Sangat Tidak Setuju (STS) sampai dengan angka 7 mewakili Sangat Setuju (SS). Alat analisa yang digunakan adalah dengan menggunakan analisis uji asosisi (hubungan) 2 variabel Nominal, dengan pengolahan data dibantu software SPSS versi 15.

\section{HASIL}

Setelah kuesioner yang disebarkan kepada responden telah disi dan telah terkumpul, sehingga didapatkanlah kuesioner yang layak untuk diolah, yaitu sebanyak 300 sampel dari populasi yang ada.

Maka dilakukan analisis terhadap sampel untuk melihat hubungan yang nyata antara perbedaan gender dengan minat beli pakaian jadi, dan pengaruh dari perbedaan gender terhadap minat beli konsumen dalam membeli pakaian jadi, pengolahan data yang ada dengan menggunakan software SPSS versi 15 .

Dari analisis yang dilakukan maka kita dapat mengukur seberapa besar hubungan yang nyata antara perbedaan gender dengan minat beli pakaian jadi, dan seberapa besar pengaruh dari perbedaan gender terhadap minat beli konsumen dalam membeli pakaian jadi.

Dimana hasil analisis dengan uji asosisi (hubungan) 2 variabel nominal untuk mengetahui apakah pernyataan hipotesis dapat ditrima atau tidak.

Dimana hasil analisis uji asosisi (hubungan) 2 variabel nominal yang dapat dilihat dari output SPSS, berupa print out Chi-Square Test dan Symmentic Measures.

Tabel 1. Output SPSS Chi-Square Test, Data Olahan SPSS

Chi-Square Tests

\begin{tabular}{|l|r|r|r|}
\hline & \multicolumn{1}{|c|}{ Value } & \multicolumn{1}{c|}{ df } & \multicolumn{1}{c|}{$\begin{array}{c}\text { Asymp. Sig. } \\
\text { (2-sided) }\end{array}$} \\
\hline Pearson Chi-Square & $30.485^{\mathrm{a}}$ & 11 & .001 \\
Likelihood Ratio & 34.331 & 11 & .000 \\
Linear-by-Linear & 13.410 & 1 & .000 \\
Association & 300 & & \\
N of Valid Cases & & & \\
\hline
\end{tabular}

a. 11 cells ( $45.8 \%)$ have expected count less than 5 . The minimum expected count is .65 .
Tabel 2. Output SPSS Symmentric Measures, Data Olahan SPSS

Symmetric Measures

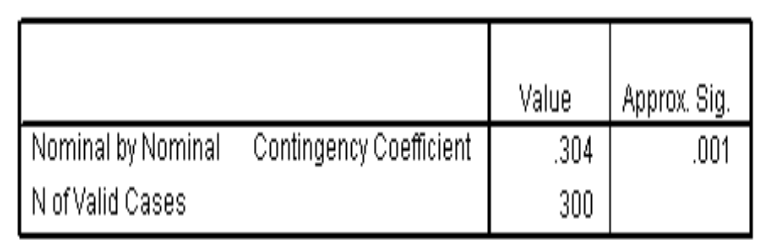

a. Not assuming the null hypothesis.

b. Using the asymptotic standard error assuming the null hypothesis.

Dari print out SPSS dapat dilihat nilai Asymp. Sig Pearson Chi-square yang sebesar $0,001<0,05$, maka ini menunjukan bahwa memang ada hubungan yang nyata antara perbedaan gender dengan minat beli pakaian jadi. Karena apabila Asymp. Sig Pearson Chi-square yang besar dari 0,05, maka terdapat hubungan antara satu variabel dengan variabel lainnya.

Jadi dapat digeneralisasi bahwa perbedaan jenis kelamin (gender) memang mempunyai hubungan dengan jenis ataupun model pakaian jadi yang dibeli ataupun yang dipilih oleh konsumen pakaian jadi.

Maka Hipotesis pertama yaitu Diduga terdapat hubungan antara perbedaan gender konsumen dengan jenis pakaian jadi yang dibeli atau dipilihnya, dapat diterima dalam hasil penelitian.

Dari print out SPSS terlihat nilai contingency coefficien yang sebesar 0,340 dan signifikan, data ini menunjukkan bahwa ada pengaruh yang cukup kuat dari perbedaan gender terhadap minat beli konsumen dalam membeli pakaian jadi.

Hipotesis kedua yaitu diduga terdapat pengaruh yang nyata dari perbedaan gender konsumen terhadap jenis pakaian jadi yang dibeli atau dipilihnya, diterima di dalam hasil penelitian.

Maka dapat dibuat penjelasan bahwa perbedaan jenis kelamin (gender) memang mempengaruhi konsumen didalam membeli ataupun memilih pakaian jadi.

Hal ini mungkin disebabkan oleh jenis kelamin yang berbeda membuat seorang konsumen memilih pakaian jadi yang sesuai dengan keinginannya berdasarkan jenis kelamin yang dimiliki oleh konsumen intu 
sendiri, walaupun pada zaman sekarang pakaian jadi seperti kaos, kemeja, ataupun celana yang didesain, bisa untuk kedua jenis kelamin, namun perbedaan jenis kelamin membuat seseorang konsumen memilih pakaian jadi yang disesuaikan dengan jenis kelaminnya.

Seorang konsumen memutuskan untuk membeli pakaian jadi yang bisa membuat dirinya kelihatan lebih maskulin apabila konsumennya adalah seorang pria, ataupun sesorang konsumen akan memutuskan untuk memilih pakaian yang akan dipakainya yang bisa membuat dirinya kelihatan lebih feminim dan anggun untuk seorang konsumen yang berjenis kelamin wanita.

Jadi dengan kata lain walaupun produk pakaian jadi, baik itu baju atau celana yang di desain dan diproduksi untuk bisa dipakai oleh jenis kelamin pria dan wanita, namun seorang konsumen tidak mau membeli pakaian jadi yang bersifat untuk semua gender tersebut, karena seorang konsumen sangat mempertimbangkan faktor perbedaan jenis kelamin (gender) didalam memilih pakain.

Karena memang perilaku seorang konsumen tidak bisa disamakan dengan perilaku konsumen lainya, karena setiap konsumen mempunyai pribadi yang unik, sesuai dengan karakteristik diri yang melekat atau dimilikinya masing-masing. Karena kebutuhan dan keinginan setiap orang berbeda.

\section{SIMPULAN}

Dari hasil penelitian maka dapat disimpulkan memang ada hubungan yang nyata antara perbedaan gender dengan minat beli konsumen pakaian jadi. Dilihat dari nilai Asymp. Sig Pearson Chi-square yang besar dari 0,05, maka terdapat hubungan antara satu variabel dengan variabel lainnya.

Hasil penelitian menunjukan bahwa ada pengaruh yang cukup kuat dari perbedaan gender terhadap minat beli konsumen pakaian jadi. Terlihat nilai contingency coefficien yang sebesar 0,340 dan signifikan, data ini menunjukkan bahwa ada pengaruh yang cukup kuat dari perbedaan gender terhadap minat beli konsumen dalam membeli pakaian jadi.

\section{DAFTAR RUJUKAN}

Assael, H., Consumers Behavior and Marketing Action, Edisi 3, Kent Publishing Company, Boston Massachusset, AS, 2002.

Boyd W, Walker Orville, C Larreche, Claude Jean, Managemen Pemasaran : Suatu Pendekatan Strategis dengan Orientasi Global, Penerbit Erlangga, Jakarta, 2000.

Jr Charles W. Lamb, Jr Joseph, F. Hair, Macdaniel Carl, 2001. Pemasaran. Edisi I (terjemahan), Penerbit Salemba Empat, Jakarta, 2001.

Kotler, Philip, Marketing Management, The Millenium Edition, Prentice Hall, Inc, 2002.

R.V Foster, Timothy, 101 Cara Meningkatkan Kepuasan Pelanggan. Edisi I (Terjemahan), Penerbit PT. Elex Media Komputindo Kelompok Gramedia, Jakarta, 1999.

Simamora, Henry, Manajemen Pemasaran Internasional, Penerbit Salemba Empat, Jakarta, 2000.

Swasta, Basu, Manajemen Pemasaran, Penerbit Liberty, Jakarta, 2000.

Umar, Husein, Studi Kelayakan Binis, Edisi kedua, Gramedia Pustaka Utama, Jakarta, 2003. 